\title{
IMPLEMETASI APLIKASI PENGELOLAAN INFORMASI PADA SEKOLAH LUAR BIASA NEGERI 1 PALANGKA RAYA BERBASIS WEB MOBILE
}

\author{
Ferdiyani Haris $^{1}$, Norhayati ${ }^{2}$ \\ ${ }^{1,2)}$ Program Studi Informasi, STMIK Palangkaraya \\ Jalan G. Obos, No. 114, Palangka Raya, Kalimantan Tengah, Indonesia \\ Email: sabila006@gmail.com, inoynorhavati@gmail.com
}

\begin{abstract}
ABSTRAK
Penyampaian infomasi internal pada Sekolah Luar Biasa Negeri (SLBN) 1 Palangka Raya masih dilakukan secara konvensional; yakni dengan menggunakan sarana pesan singkat, memo tertulis/surat dan penulisan pada papan pengumuman. Sementara itu untuk pengumuman yang sifatnya insidentil maka pemberitahuannya dituliskan pada papan pengumuman. Hal ini acapkali menyebabkan terjadinya kekeliruan tentang informasi terbaru tentang kegiatan yang ada disekolah tersebut. Sistem Informasi Sekolah Luar Biasa Negeri 1 Palangka Raya ini dibangun dengan bahasa pemrograman PHP, HTML dan MySQL. Jenis penelitian yang digunakan adalah Research and Development (R\&D). Metode pengembangan sistem yang digunakan adalah System Development Life Cycle (SDLC) yang terdiri dari beberapa tahapan, antara lain : Analisis, Perancangan, Implementasi dan pengujian unit, Integrasi dan pengujian sistem, Operasi dan pemeliharaan. Untuk alat bantu perancangan sistem menggunakan Unified Modeling Language (UML).
\end{abstract}

Kata Kunci : Pengelolaan Informasi, Sekolah Luar Biasa, Web Mobile

\section{ABSTRACT}

Internal information submission to the Palangka Raya 1 Special School (SLBN) is still done conventionally; using short means, written memos / messages and services on the bulletin board. Meanwhile, for announcements that are incidental in nature, the notification is written on the notice board. This often causes confusion about the latest information about the activities at the school. The Information System for the Special School 1 Palangka Raya was built with the programming languages PHP, HTML and MySQL. The type of research used is Research and Development (R\&D). The system development method used is the System Development Life Cycle (SDLC) which consists of several stages, including: Analysis, Design, Implementation and unit testing, integration and system testing, operation and maintenance. For system design tools using the Unified Modeling Language (UML).

Keywords: Information Management, Special School, Mobile Web

\section{PENDAHULUAN}

Perkembangan teknologi informasi dan komunikasi telah melahirkan model pelayanan informasi baru yang dilakukan melalui perkembangan teknologi internet. Teknologi internet sudah terbukti merupakan salah satu media informasi yang efektif dan efisien dalam penyebaran informasi yang dapat diakses oleh siapa saja, kapan saja dan dimana saja. Pengembangan jaringan komunikasi data antar komputer maupun antar perangkat lain seperti halnya Gadget dan Smartphone menjadikan internet muncul dengan berbagai macam aplikasi internet khususnya seperti web berbasis mobile.

Proses penyampaian informasi yang ada di Sekolah Luar Biasa Negeri 1 Palangka Raya masih dilakukan secara konvesional. Dimana pihak administrasi mengirimkan surat tertulis kepada para guru dan tenaga usaha untuk hal-hal yang bersifat undangan. Sementara itu untuk pengumuman yang sifatnya insidentil maka pemberitahuannya dituliskan pada papan pengumuman. Hal ini acapkali 
menyebabkan terjadinya kekeliruan tentang informasi terbaru tentang kegiatan yang ada disekolah tersebut.

Dengan melihat permasalahan di atas maka di butuhkan sebuah web mobile yang dapat melihat penjadwalan agenda kegiatan kepala sekolah, agenda kegiatan guru dan tenaga kependidikan, dan informasi rapat. Alasan digunakannya web berbasis mobile untuk website ini adalah untuk mempermudah pengguna dalam melihat jadwal agenda kegiatan melalui perangkat mobile yang bisa diakses kapanpun.

Berdasarkan uraian diatas, maka perumusan masalah yang dibahas dalam penulisan ini adalah bagaimana merancang dan membangun sistem informasi Sekolah Luar Biasa Negeri 1 Palangka Raya berbasis web mobile.

\section{METODE}

Metode yang gunakan dalam pengembangan aplikasi pengelolaan informasi ini adalah model air terjun (waterfall model).

Waterfall Model adalah suatu proses, pengembangan, percontohan, dimana membangun suatu sistem yang mengalir bergerak dari atas ke bawah yang menyediakan pendekatan alur hidup pengembangan perangkat lunak secara sekuential atau terurut.

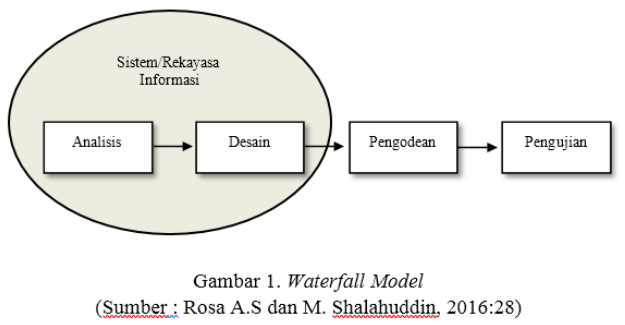

Tahapan metode waterfall yang dilakukan adalah sebagai adalah sebagai berikut:

1. Software Requirement Analysis

Pada tahap ini, dilakukan Analisa sistem yang telah berjalan pada SLB Negeri 1 Palangka Raya. Untuk mengidentifikasi dan memberikan solusi terhadap masalah yang ada. Digunakan metode 4 tahapan untuk mengetahui kelemahan pada sistem yang selama ini berjalan. Metode analisis 4 tahapan tersebut adalah identify, understand, analyze, dan report.

\section{System Design}

Metode perancangan yang digunakan adalah UML (Unified Modeling Language). Adapun diagram yang digunakan dalam desain sistem adalah use case diagram, activity diagram, dan sequence diagram menggunakan StartUML. Untuk pengembangan program menggunakan PHP, sementara itu untuk menjalankan program yang sudah menggunakan Notepad ++ .

\section{Implementation}

Dalam tahap ini, hasil dari desain perangkat lunak direalisasikan sebagai satu set program atau unit program berdasarkan desain "blueprint" yang telah dibuat. Pengembangan sistem dilakukan dari awal hingga siap dijalankan, serta termasuk fungsi-fungsi yang dibutuhkan hingga tampilan untuk pengguna.

\section{Testing}

Tahapan pengujian pada aplikasi yang diterapkan dilakukan dengan menggunakan metode blackbox testing.

Menurut Rosa dan Salahuddin (2016:275) Black Box Testing (Pengujian Kotak Hitam), yaitu menguji perangkat lunak dari segi spesifikasi fungsional tanpa menguji desain dan kode program. Pengujian dimaksudkan untuk mengetahui apakah fungsi-fungsi, masukkan dan keluaran dari perangkat lunak sesuai dengan spesifikasi yang dibutuhkan.

\section{Maintenance}

Pemeliharaan suatu software diperlukan, termasuk didalamnya adalah pengembangan, karena software yang dibuat tidak selamanya hanya seperti itu. Pemeliharaan sistem akan menjadi tanggungjawab pihak yang menggunakan sistem.

\section{HASIL DAN PEMBAHASAN}

1. Hasil Perancangan Sistem

Alat bantu analisis dalam pembuatan dan perancangan sistem ini menggunakan UML (Unified Modeling Language). Menurut Triandini dan Suardika (2012:1) StarUML adalah platform pemodelan perangkat lunak yang mendukung UML (Unified Modeling Language). StarUML yang berbasiskan pada UML versi 1.4 , menyediakan sebelas jenis Diagram yang berbeda, dan mendukung notasi UML 2.0 StarUML juga 


$$
\begin{array}{r|l}
\text { Jurnal Sains Komputer dan Teknologi Informasi } & \text { Page } \\
\text { e-issn: 2655-7460. Volume } 3 \text { No.1, November } 2020 & \text { i-9 }
\end{array}
$$

secara aktif mendukung pendekatan MDA (Model Driven Architecture) dengan mendukung konsep UML profile.

Adapun diagram yang digunakan adalah Use Case Diagram, Activity Diagram, dan Sequence Diagram.

a. Use case diagram

Dalam pengembangan use case diagram, terdapat dua aktor yaitu admin dan user, dimana use case ini merupakan suatu desain proses dari rancangan sistem. use case diagram dapat dilihat pada gambar berikut ini

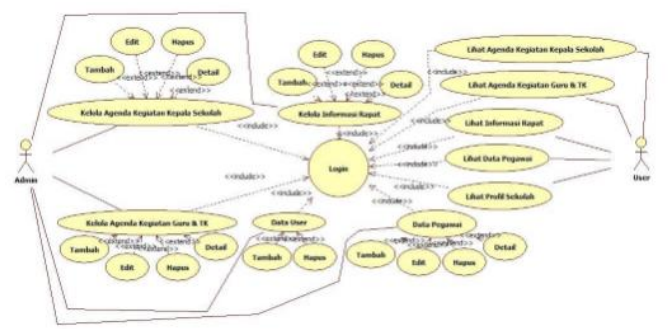

Gambar 2. Use Case Diagram

b. Activity diagram

Activity Diagram Login dimana admin dan user mengisi username dan password kemudian menekan tombol Login selanjutnya sistem akan mengecek username dan password di database jika benar akan masuk ke menu utama dan jika salah akan kembali ke form login.

\section{Activity Diagram Data Pegawai (Admin)}

Admin memilih Data Pegawai sistem akan menampilkan seluruh agenda kegiatan guru dan tenaga kependidikan kemudian admin dapat Tambah, Edit, Hapus, dan Detail

2. Activity Diagram Data User (Admin)

Admin memilih Data User kemudian sistem akan menampilkan seluruh data user kemudian admin dapat menambah user dan menghapus user.

3. Agenda Kegiatan Kepala Sekolah (Admin)

Admin memilih agenda kegiatan kepala sekolah sistem akan menampilkan seluruh agenda kegiatan kepala sekolah kemudian admin dapat Tambah, Edit, Hapus, dan Detail.
4. Activity Diagram Agenda
Kegiatan Guru dan Tenaga
Kependidikan (Admin)

Admin memilih agenda kegiatan guru dan tenaga kependidikan dan sistem akan menampilkan seluruh agenda kegiatan guru dan tenaga kependidikan yang sudah pernah ditambahkan kemudian admin dapat Tambah, Edit, Hapus, dan Detail

5. Activity Diagram Informasi Rapat (Admin)

Admin memilih informasi rapat dan sistem akan menampilkan seluruh informasi rapat yang sudah pernah ditambahkan kemudian admin dapat Tambah, Edit, Hapus, dan Detail.

6. Melihat Agenda Kegiatan (User) Saat User berhasil login maka sistem akan menampilkan agenda kegiatan kepala sekolah, menampilkan agenda kegiatan guru dan tenaga kependidikan, dan menampilkan informasi rapat, dan saat user menekan Detail maka sistem akan memproses.

7. Activity Diagram Melihat Profil Sekolah (User)

User memilih Profil Sekolah maka sistem akan menampilkan profil Sekolah

8. Activity Diagram Melihat Data Pegawai (User)

User memilih data pegawai maka sistem akan menampilkan data pegawai.

c. Sequence Diagram

Berikut ini merupakan sequence diagram yang disusun, yakni:

1) Sequence Diagram Login (Admin dan User)

Admin atau user mengakses sistem agenda kegiatan dan menampilkan sistem kepada admin atau user kemudian admin atau user mengakses form login dan mengisi username dan password jika username dan password ada 
pada database maka sistem akan masuk kemenu utama dan jika username dan password salah maka akan menampilkan pesan username atau password Salah dan kembali ke form login.

2) Sequence Digram Data Pegawai Tambah Pegawai (Admin)

Admin mengakses beranda dan akan menampilkan beranda, kemudian admin memilih data pegawai dan menampilkan form menu untuk menambah data pegawai, lalu admin mengisi data pegawai dan menyimpan data pegawai ke database, lalu akan menampilkan pesan Sukses! Data Pegawai Berhasil Ditambahkan.

3) Sequence Diagram Data Pegawai Edit Pegawai (Admin)

Admin mengakses beranda dan akan menampilkan beranda, kemudian admin memilih data pegawai dan menampilkan form menu untuk mengedit data pegawai, lalu admin mengedit data pegawai dan menyimpan data pegawai ke database, lalu akan menampilkan pesan

Sukses! Data Pegawai Berhasil Diubah.

4) Sequence Diagram Data Pegawai Hapus Pegawai (Admin)

Admin mengakses beranda dan akan menampilkan beranda, lalu admin memilih data pegawai, klik icon hapus dan akan menghapus data di database, dan akan menampilkan pesan Sukses! Data Pegawai Berhasil Dihapus.

5) Sequence Diagram Data Pegawai Detail Pegawai (Admin)

Admin mengakses beranda dan akan menampilkan beranda, lalu admin memilih data pegawai, dan mengklik icon detail dan akan mengecek ke database lalu akan menampilkan detail data pegawai.

6) Sequence Diagram Data User Tambah User (Admin)

Admin mengakses beranda dan akan menampilkan beranda, kemudian pilih data user kemudian akan menampilkan form tambah data user, selanjutnya admin mengisi username dan password dan menyimpan ke database, jika berhasil disimpan maka akan menampilkan pesan Sukses! User Berhasil Ditambahkan.

7) Sequence Diagram Data User Hapus User (Admin)

Admin mengakses beranda dan akan menampilkan beranda, kemudian pilih data user dan akan menampilkan data user, lalu pilih user yang ingin dihapus, maka akan menghapus user yang ada di database, kemudian akan menampilkan pesan Sukses! User Berhasil Dihapus.

8) Sequence Diagram Tambah Agenda Kegiatan Kepala Sekolah (Admin)

Admin mengakses beranda dan akan menampilkan beranda, kemudian admin memilih agenda kegiatan kepala sekolah dan menampilkan form menu untuk menambah agenda kegiatan, lalu admin mengisi agenda kegiatan dan menyimpan agenda ke database, lalu akan menampilkan pesan Sukses! Agenda Kegiatan Kepala Sekolah Berhasil Ditambahkan.

9) Sequence Diagram Edit Agenda Kegiatan Kepala Sekolah (Admin)

Admin mengakses beranda dan akan menampilkan beranda, kemudian admin memilih agenda kegiatan kepala sekolah 


$$
\begin{array}{r|l}
\text { Jurnal Sains Komputer dan Teknologi Informasi } & \text { Page } \\
\text { e-issn: 2655-7460. Volume } 3 \text { No.1, November } 2020 & \text { i-9 }
\end{array}
$$

dan menampilkan form menu untuk mengedit agenda kegiatan, lalu admin mengedit agenda kegiatan dan menyimpan agenda ke database, lalu akan menampilkan pesan Sukses! Agenda Kegiatan Kepala Sekolah Berhasil Diubah.

10) Sequence Diagram Hapus Agenda Kegiatan Kepala Sekolah (Admin)

Admin mengakses beranda dan akan menampilkan beranda, lalu admin memilih agenda kegiatan kepala sekolah, klik icon hapus dan akan menghapus data di database, dan akan menampilkan pesan Sukses! Agenda Kegiatan Kepala Sekolah Berhasil Dihapus.

11) Sequence Diagram Detail Agenda Kegiatan Kepala Sekolah (Admin) Admin mengakses beranda dan akan menampilkan beranda, lalu admin memilih agenda kegiatan kepala sekolah, dan mengklik icon detail dan akan mengecek ke database lalu akan menampilkan detail agenda kegiatan.

12) Sequence Diagram Tambah Agenda Kegiatan Guru dan Tenaga

Kependidikan (Admin)

Admin mengakses beranda dan akan menampilkan beranda, kemudian admin memilih agenda kegiatan guru dan tenaga kependidikan dan menampilkan form menu untuk menambah agenda kegiatan, lalu admin mengisi agenda kegiatan dan menyimpan agenda ke database, lalu akan menampilkan pesan Sukses! Agenda Kegiatan Guru dan Tenaga Kependidikan Berhasil Ditambahkan.
13) Sequence Diagram Edit Agenda Kegiatan Guru dan Tenaga Kependidikan (Admin)

Admin mengakses beranda dan akan menampilkan beranda, kemudian admin memilih agenda kegiatan guru dan tenaga kependidikan dan menampilkan form menu untuk mengedit agenda kegiatan, lalu admin mengedit agenda kegiatan dan menyimpan agenda ke database, lalu akan menampilkan pesan Sukses! Agenda Kegiatan Guru dan Tenaga Kependidikan Berhasil Diubah.

14) Hapus Agenda Kegiatan Guru dan Tenaga Kependidikan (Admin)

Admin mengakses beranda dan akan menampilkan beranda, lalu admin memilih agenda kegiatan guru dan tenaga kependidikan, klik icon hapus dan akan menghapus data di database, dan akan menampilkan pesan Sukses! Agenda Kegiatan Guru dan Tenaga Kependidikan Berhasil Dihapus.

15) Sequence Diagram Detail Agenda Kegiatan Guru dan Tenaga Kependidikan (Admin)

16) Admin mengakses beranda dan akan menampilkan beranda, lalu admin memilih agenda kegiatan guru dan tenaga kependidikan, dan mengklik icon detail dan akan mengecek ke database lalu akan menampilkan detail agenda kegiatan.

17) Sequence Diagram Tambah Informasi Rapat (Admin)

Admin mengakses beranda dan akan menampilkan beranda, kemudian admin memilih informasi rapat dan menampilkan form menu untuk menambah informasi rapat, lalu admin mengisi informasi rapat dan menyimpan informasi rapat 
ke database, lalu akan menampilkan pesan Sukses! Informasi Rapat Berhasil Ditambahkan.

18) Sequence Diagram Hapus Informasi Rapat (Admin)

Admin mengakses beranda dan akan menampilkan beranda, lalu admin memilih Informasi Rapat, klik icon hapus dan akan menghapus data di database, dan akan menampilkan pesan Sukses!

Informasi Rapat Berhasil Dihapus.

19) Sequence Diagram Detail Informasi Rapat (Admin)

Admin mengakses beranda dan akan menampilkan beranda, lalu admin memilih informasi rapat, dan mengklik icon detail dan akan mengecek ke database lalu akan menampilkan detail agenda kegiatan.

20) Melihat Agenda (User)

User mengakses halaman utama, maka sistem akan menampilkan halaman utama, lalu user memilih detail dan sistem akan mengecek ke database dan akan menampilkan agenda kegiatan secara lebih lengkap.

21) Sequence Diagram Profil Sekolah (User)

User mengakses halaman utama, maka akan menampilkan halaman utama, user memilih profil sekolah, maka akan menampilkan profil sekolah.

22) Sequence Diagram Data Pegawai (User)

User mengakses halaman utama, maka akan menampilkan halaman utama, user memilih data pegawai, maka sistem akan mengecek ke database, dan akan menampilkan data pegawai.

\section{d. Class Diagram}

Berikut adalah class diagram Sistem Informasi Sekolah Luar Biasa Negeri 1 Palangka Raya.

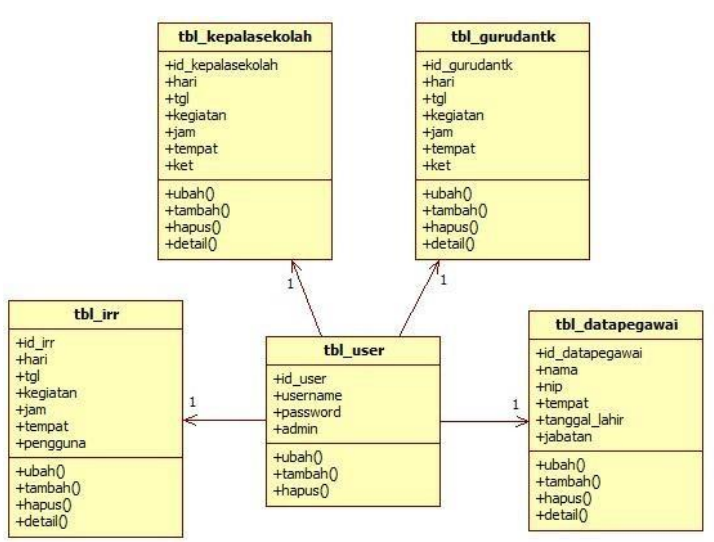

Gambar 3. Class Diagram

2. Hasil Implementasi Perancangan Sistem Implementasi sistem merupakan tahap dimana penulis akan menjelaskan bagaimana aplikasi yang telah dibuat bekerja sesuai yang diharapkan dapat berjalan dengan baik, meliputi uji coba sistem dan program dengan menggunakan black box testing sehingga dengan melakukan uji coba penulis dapat mengetahui kelemahan dan kelebihan sistem yang telah di buat.

Aplikasi ini dapat berjalan dengan ketentuan:

1) Perangkat laptop atau telepon genggam memiliki web browser dan terkoneksi kejaringan internet;

2) Pengguna telah terdaftar dalam aplikasi dan disetujui oleh admin;

3) Admin telah memasukan dan melalukan pembaharuan data atau informasi kedalam aplikasi.

Black box testing yang dilakukan meliputi beberapa pengujian yang dapat dikelompokan pada tabel 1 .

\begin{tabular}{|c|c|}
\hline Jenis Pengujian & $\begin{array}{c}\text { Kriteria Evaluasi } \\
\text { Hasil }\end{array}$ \\
\hline
\end{tabular}




\begin{tabular}{|c|c|}
\hline Pengujian Login & $\begin{array}{l}\text { Mengisi form login } \\
\text { untuk masuk ke } \\
\text { halaman utama } \\
\text { berdasarkan hak } \\
\text { aksesnya }\end{array}$ \\
\hline Halaman Data Pegawai & $\begin{array}{l}\text { Menambah data, } \\
\text { mengedit data, } \\
\text { menghapus data, } \\
\text { melihat detail dan } \\
\text { pencarian data. }\end{array}$ \\
\hline Halaman Data User & $\begin{array}{l}\text { Menambah data, } \\
\text { mencari data dan } \\
\text { menghapus data. }\end{array}$ \\
\hline $\begin{array}{l}\text { Halaman Agenda Kepala } \\
\text { Sekolah }\end{array}$ & $\begin{array}{l}\text { Menambah data, } \\
\text { mengedit data, } \\
\text { menghapus data, } \\
\text { melihat detail dan } \\
\text { pencarian data. }\end{array}$ \\
\hline $\begin{array}{l}\text { Halaman Agenda Guru } \\
\text { dan Tenaga } \\
\text { Kependidikan }\end{array}$ & $\begin{array}{l}\text { Menambah data, } \\
\text { mengedit data, } \\
\text { menghapus data, } \\
\text { melihat detail dan } \\
\text { pencarian data. }\end{array}$ \\
\hline Halaman Informasi Rapat & $\begin{array}{l}\text { Menambah data, } \\
\text { mengedit data, } \\
\text { menghapus data, } \\
\text { melihat detail dan } \\
\text { pencarian data. }\end{array}$ \\
\hline $\begin{array}{l}\text { Halaman Profile Ubah } \\
\text { Username dan Password }\end{array}$ & $\begin{array}{l}\text { Mengubah } \\
\text { username dan } \\
\text { password }\end{array}$ \\
\hline Halaman Profile Sekolah & Melihat profile \\
\hline $\begin{array}{l}\text { Halaman Kirim } \\
\text { Notifikasi }\end{array}$ & $\begin{array}{l}\text { Mengirim } \\
\text { notifikasi }\end{array}$ \\
\hline User Melihat Detail & $\begin{array}{l}\text { Melihat Detail } \\
\text { Keseluruhan }\end{array}$ \\
\hline $\begin{array}{l}\text { User Mengubah } \\
\text { Username dan Password }\end{array}$ & $\begin{array}{l}\text { Mengubah } \\
\text { username dan } \\
\text { password }\end{array}$ \\
\hline
\end{tabular}

Halaman Login

Pengguna Sistem

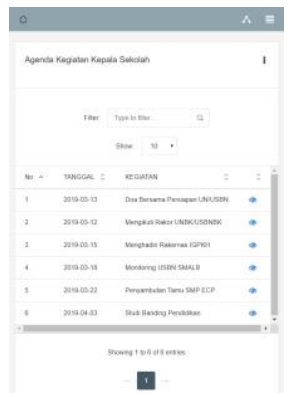

Gambar 6.

Halaman

Utama User

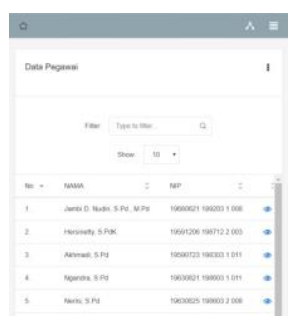

Gambar 8. Lihat

Data Pegawai

(User)

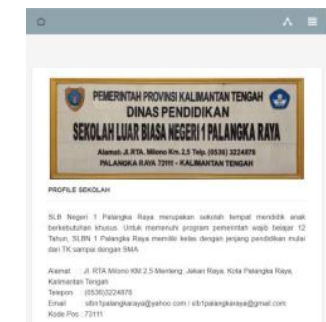

Gambar 9. Lihat

Profil Sekolah

(User)

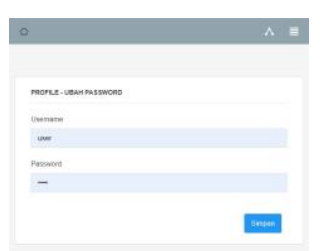

Gambar 10. Form Ubah Username dan

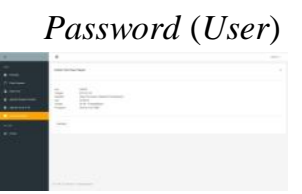

Gambar 11. Form Detail Informasi Rapat (Admin)

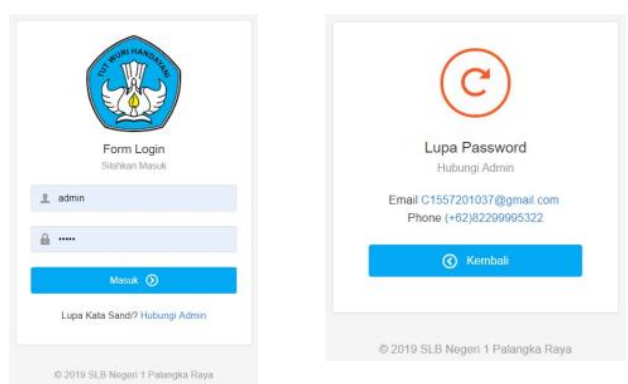

Gambar 4.
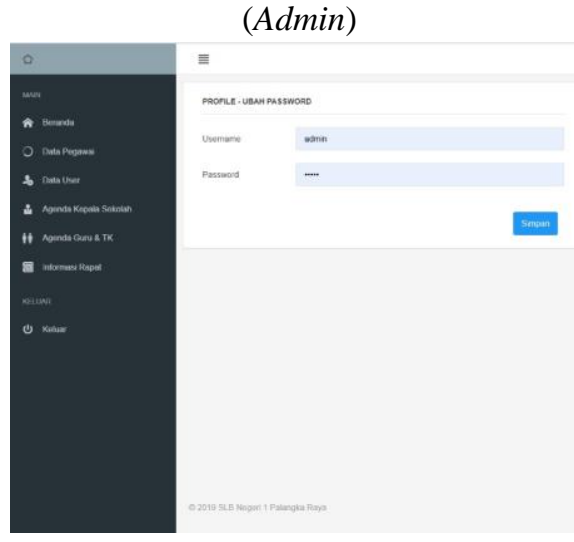
Gambar 72. Form Ubah Username dan Password (Admin)

\section{KESIMPULAN DAN SARAN}

A. Kesimpulan

1. Implemetasi aplikasi pengelolaan informasi Sekolah Luar Biasa Negeri 1 Palangka Raya Berbasis Web Mobile ini dirancang dan di bangun dengan menggunakan pemrograman $P H P, H T M L$ dan MySQL.

2. Sistem ini dapat mengelola agenda kegiatan kepala sekolah, agenda kegiatan guru dan tenaga kependidikan dan informasi rapat.

3. Berdasarkan dari hasil uji coba dengan menggunakan metode black box testing dapat disimpulkan bahwa website yang dibangun telah sesuai dengan desain yang dibuat.

B. Saran

Adapun saran yang dapat berikan setelah proses pembuatan Sistem Informasi Sekolah Luar Biasa Negeri 1 Palangka Raya Berbasis Web Mobile ini, maka saran-saran untuk pengembangan selanjutnya adalah sebaiknya sistem sebagai berikut:

1. Pada penelitian selanjutnya diharapkan adanya pengembangan aplikasi menjadi berbasis android, sehingga dapat menjangkau semua sistem operasi yang digunakan oleh user.

2. Dalam pengembangan aplikasi kedepannya, diharapkan dapat menambahkan fitur notifikasi berupa sms gateway.

3. Dalam penggunaan aplikasi ini, diharapkan admin melakukan proses back up data secara rutin.

\section{DAFTAR PUSTAKA}

Abdulloh R., 2015. Web Programing is Easy, PT Elex Media Komputindo, Jakarta. Abdurahman M., 2016. Sistem Informasi Jadwal Perkuliahan Berbasis Web Mobile pada Politeknik Sains dan Teknologi Wiratama Maluku Utara. Indonesian Journal on Networking and security - Volume 5 No 2 - Mei 2016.

Djahir, Yulia., 2014. Bahan Ajar Sistem Informasi Manajemen. Deepublish. Jakarta. Erfan M., 2018. BHC Book Series:

Pemrograman WEB (PDO + MySQL), Diandra Kreatif, Yogyakarta.

Kadir A., 2014. Pengenalan Sistem Informasi, ANDI, Yogyakarta.

Karman J., dan Arifin, Z.A. 2018. Aplikasi Delivery Order Berbasis Web Mobile Pada Trotoar Steak, Jurnal Teknologi Informasi dan Komputer Politeknik Sekayu Vol.9 No.2:38.

MADCOMS., 2016. Pemrograman PHP dan MySQL untuk Pemula, ANDI, Yogyakarta.

Mahatmyo A., 2014. Sistem Informasi Akuntansi Suatu Pengantar, Deepublish, Jakarta.

McLeod R., 2018. Sistem Informasi

Manajemen, Edisi 10, Selemba Empat, Jakarta.

Munawar., 2018. Analisis Perancangan Sistem Berorientasi Objek dengan UML, Informatika, Bandung.

Purbadian Y., 2016. Trik Cepat Membangun

Aplikasi Berbasis Web dengan Framework

CodeIgniter, ANDI, Yogyakarta.

Karman J., dan Arifin, Z.A. 2018. Aplikasi

Delivery Order Berbasis Web Mobile

Pada Trotoar Steak, Jurnal Teknologi Informasi dan Komputer Politeknik Sekayu Vol.9 No.2:38.

MADCOMS., 2016. Pemrograman PHP dan MySQL untuk Pemula, ANDI, Yogyakarta.

Mahatmyo A., 2014. Sistem Informasi Akuntansi Suatu Pengantar, Deepublish, Jakarta.

McLeod R., 2018. Sistem Informasi

Manajemen, Edisi 10, Selemba Empat, Jakarta. 
Munawar., 2018. Analisis Perancangan Sistem Berorientasi Objek dengan UML, Informatika, Bandung.

Purbadian Y., 2016. Trik Cepat Membangun Aplikasi Berbasis Web dengan Framework CodeIgniter, ANDI, Yogyakarta.

Putra N., 2011. Research and Development, PT.

Raja Grafindo Persada, Jakarta.

Shalahuddin, dan Rosa. 2016. Rekayasa Perangkat Lunak Terstruktur dan Berorientasi Objek, Informatika, Bandung.

Sugiyono, 2013. Metode Penelitian Kuantitatif, Kualitatif, dan $R \& D$, ALFABETA, Bandung.
Sugiyono, P.D., 2015. Metode Penelitian Pendidikan, ALFABETA, Bandung.

Sutabri T, 2016. Analisis Sistem Informasi, CV.

Andi Offset, Yogyakarta.

Triandini, dan Suardika. 2012. Step by Step Desain Proyek Menggunakan UML, ANDI, Yogyakarta.

Wahana Komputer. 2012. Belajar Javascript Menggunakan JQuery, ANDI, Yogyakarta.

Wahyono, 2015. Konsep Sistem Informasi, Graha Ilmu, Yogyakarta. 